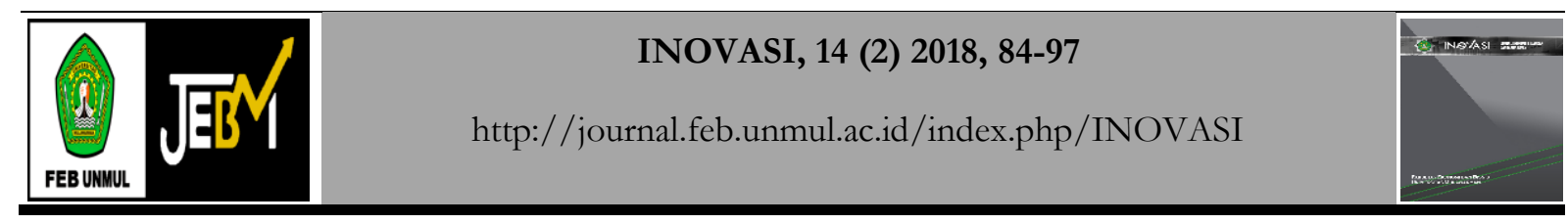

\title{
Pengaruh kualitas produk terhadap kepuasan pelanggan keripik nenas di desa kualu nenas kecamatan tambang kabupaten kampar provinsi riau
}

\author{
Dewi Sartika ${ }^{1}$, Agustin Basriani ${ }^{2}$ \\ Akademi Sekretari dan Manajemen Persada Bunda Pekanbaru \\ Email: dewiarelagha@gmail.com \\ ${ }^{2}$ Email: agustin.basriani@gmail.com
}

\begin{abstract}
Abstrak
Penelitian ini bertujuan untuk mengetahui pengaruh kualitas produk terhadap kepuasan pelanggan keripik nenas di Desa Kualu Nenas Kecamatan Tambang Kabupaten Kampar Provinsi Riau. Desa Kualu Nenas merupakan desa yang terkenal dengan hasil pertaniannya yaitu buah nenas. Buah nenas tersebut diolah menjadi keripik nenas, yang merupakan oleh-oleh khas daerah tersebut. Populasi dalam penelitian ini adalah pelanggan yang telah melakukan pembelian keripik nenas minimal dua kali di Desa Kualu Nenas Kecamatan Tambang Kabupaten Kampar Provinsi Riau. Dengan asumsi jumlah pelanggan tidak dapat diketahui dengan pasti, maka jumlah sampel ditentukan dengan rumus Wibisono, yaitu sebanyak 96 pelanggan. Dari hasil penelitian diperoleh bahwa : 1) kualitas produk yaitu fitur dan desain berpengaruh secara parsial terhadap kepuasan pelanggan keripik nenas di Desa Kualu Nenas Kecamatan Tambang Kabupaten Kampar Provinsi Riau, sedangkan kualitas produk lainnya kinerja, kehandalan, daya tahan dan kesesuaian tidak berpengaruh terhadap kepuasan pelanggan keripik nenas di Desa Kualu Nenas Kecamatan Tambang Kabupaten Kampar Provinsi Riau, 2) kualitas produk yang terdiri dari kinerja, kehandalan, fitur, daya tahan, kesesuaian, dan desain berpengaruh secara simultan terhadap kepuasan pelanggan keripik nenas di Desa Kualu Nenas Kecamatan Tambang Kabupaten Kampar Provinsi Riau.
\end{abstract}

Kata Kunci: kualitas produk; kepuasan pelanggan

\section{The effect of product quality on customer satisfaction of nenas chip in kualu nenas village, kecamatan tambang, kampar district, riau province}

\begin{abstract}
The purpose of this research is to know the influence of quality product for the satisfaction of pineapple crackers' costumers in Kuala Nenas Village Tambang Sub District Kampar Regency Riau Province. Kuala Nenas Village is the popular village with its' agricultural product, pineapple. Pineapple as their agricultural product. Pineapple is created become pineapple crackers, and it is the gift for the travelers who come to this village. Kualu nenas village is the traffic road. Population of this research is the costumers that have bought the pineapple crackers more than twice in Kualu nenas Village Tambang sub District Kampar Regency Riau Province. Hypothetically the amount of the costumers can't be confirmed, and then the amount of sample is determined by Wibisono's Formula, that ninety six costumers in this research are obtained as: 1).The quality of feature and design product take effect partially to the pineapple crackers' costumers' satisfaction in Kualu Nenas Village, Tambang sub District Kampar Regency Riau Province, while another product quality, performance, reliability, doesn't give influence to the costumers' satisfaction, 2). The quality of the product is created by the performance, reliability, features, resistance, suitability and design take effect strongly to the costumers' satisfaction in Kualu Nenas Village, Tambang sub District Kampar Regency Riau Province.
\end{abstract}

Keywords: Product quality; costumers' satisfaction 


\section{PENDAHULUAN}

Desa Kualu Nenas merupakan salah satu desa yang berada di Kecamatan Tambang Kabupaten Kampar Propvinsi Riau. Desa Kualu Nenas merupakan desa yang terkenal dengan hasil pertaniannya yaitu Buah Nenas. Hampir sebagian besar mata pencarian penduduk desa Kualu Nenas adalah bertani. Hal ini dapat dilihat dari luas daerah Desa Kualu Nenas yaitu 3500 Ha, 1600 Ha digunakan sebagai lahan pertanian dan perkebunan atau sekitar 45,71 \% ( Arsip Desa kualu Nenas, 2017).

Letak desa Kualu Nenas merupakan letak yang strategis, karena merupakan jalan utama lintas dari Pekanbaru menuju Sumatera Barat, begitu juga sebaliknya. Sehingga merupakan potensi yang sangat menguntungkan. Dari 17 desa yang terdapat di kecamatan Tambang, desa Kualu Nenas merupakan desa penghasil nenas terbanyak yang ditemukan. Hal ini juga yang menyebabkan pemberian nama desa Kualu Nenas (Arsip Desa Kualu Nenas,2017).

Dari hasil pertanian tersebut, buah nenas yang dihasilkan ada yang dijual langsung tanpa diolah dulu dan juga ada yang diolah menjadi keripik nenas. Keripik nenas merupakan makanan khas daerah tersebut. Keripik nenas dijadikan sebagai oleh-oleh dari Kampar. Keripik Nenas sebagian besar dijual dipinggir jalan, hanya sedikit yang dijual di supermarket atau pasar modern, bahkan ada yang sama sekali belum masuk ke supermarket.

Berdasarkan survei yang ditemukan dilapangan dan observasi terhadap 20 orang pelaku usaha keripik nenas, keripik nenas yang dihasilkan dan dijual bentuknya masih beraneka ragam, ada yang bagus, ada yang kurang, warna yang tidak merata (ada yang coklat tua, coklat muda dan kuning pucat). Ketebalan tiap potongan keripik nenas tidak seragam/sama, rasa keripik nenas dalam satu kemasan yang beraneka (ada yang asam dan manis), tingkat kerenyahan yang berbeda tiap kepingnya. Begitu juga dengan kemasan yang digunakan hanya berupa plastik bening dan disablon, yang bisa terhapus dengan mudah dan apabila termakan berdampak tidak baik bagi kesehatan. Begitu juga keripik nenas yang dijual belum memiliki sertifikat Halal, BPOM dan waktu kadarluarsa.

Dilihat dari potensi alam dan letak yang strategis Desa Kualu Nenas, pelaku usaha keripik nenas belum menghasilkan produk yang berkualitas. Sekarang ini pasar sangat sensitif terhadap produk yang berkualitas. Konsumen sangat selektif dalam pemilihan produk, apalagi begitu banyak produk yang sejenis. Oleh karena itu supaya Keripik Nenas yang dihasilkan berkualitas, tentu akan meningkatkan pembelian oleh konsumen yang nantinya akan menimbulkan rasa kepuasan terhadap Keripik Nenas dari desa Kualu Nenas.

\section{Kajian Pustaka \\ Kualitas Produk}

Produk merupakan salah satu hal yag harus diperhatikan oleh perusahaan. Karena produk memiliki peranan yang penting dalam menentukan keberhasilan suatu perusahaan. Kepuasan pelanggan berbanding lurus terhadap kualitas produk. Menurut Sudaryono (2016:207) Produk adalah sesuatu yang dapat ditawarkan kepasar untuk diperhatikan,dimiliki, dipakai, atau dikonsumsi sehingga dapat memuaskan keinginan dan kebutuhan. Dalam pengertian luas, produk mencakup apa saja yang bisa dipasarkan, temasuk benda-benda fisik, jasa manusia, tempat, organisasi, dan idea tau gagasan menurut saidi (2007) dalam sudaryono (2016:2017).

Konsep kualitas menurut Lupiyoadi (2013: 212) bersifat relatif yaitu bergantung pada perspektkif yang digunakan untuk menentukan ciri-ciri dan spesifikasi. Terdapat tiga orientasi kualitas yang seharusnya konsisten satu sama lain yaitu 1) persepsi konsumen, 2) produk, 3) proses.

Kualitas produk menurut Kotler dan Amstrong (2008:272) yaitu karakteristik produk atau jasa yang bergantung pada kemampuannya untuk memuaskan kebutuhan pelanggan yang dinyatakan atau diimplikasikan. Kualitas produk menurut Lupiyoadi (2013:212) yaitu sejauh mana produk dapat memenuhi spesifikasi-spesifikasinya. Kualitas produk dapat disimpulkan kemampuan suatu produk untuk dapat memenuhi apa yang diinginkan oleh pemakainya. Pelanggan yang merasa puas akan kembali melakukan pembelian ulang dan mereka akan memberitahu calon konsumen lainnya.

\section{Dimensi Kualitas Produk}

Berdasarkan persfektif kualitas, Garvin dalam Yamit (2010:10) mengembangkan dimensi kualitas kedalam beberapa dimensi yang dapat dijadikan sebagai dasar perencanaan strategis bagi perusahaan atau manufaktur yang menghasilkan barang, yaitu:

Kinerja (Performance): yaitu karakteristik pokok dari produk inti 
Fitur (Features): yaitu karakteristik pelengkap/tambahan

Kehandalan (Reliability):yaitu kemungkinan tingkat kegagalan pemakaian

Kesesuaian (Conformance): yaitu sejauh mana karakteristik desain dan operasi memenuhi standar-standar yang telah ditetapkan sebelumnya

Daya tahan (Durability):yaitu berapa lama produk dapat terus digunakan

Servicestability : yaitu meliputi kecepatan, kompetensi, kenyamanan, kemudahan dalam pemeliharaan, dan penanganan keluhan yang memuaskan

Estetika: yaitu menyangkut corak, rasa, dan daya tarik produk terhadapnya.

Perceived, yaitu menyangkut citra dan reputasi produk serta tanggung jawab perusahaan

Karakteristik kualitas dari suatu produk sangat multidimensional, karena produk dapat memberikan kepuasan dan nilai kepada pelanggan dalam banyak cara. Menurut Martinich dalam Yamit (2010:11) kualitas produk yang relevan dengan pelanggan dapat dikelompokkan dalam dimensi sebagai berikut:

Performance. yaitu menentukan apakah produk menggambarkan keadaan yang sebenarnya

Range and Type of features: menunjukkan kemampuan/keistimewaan yang dimiliki oleh produk dan pelayanan

Reliability and durability, kehandalan produk dalam penggunaan secara normal dan berapa lama produk dapat digunakan hingga perbaikan diperlukan

Maintainability and servicetability: kemudahan untuk pengoperasian produk dan kemudahan perbaikan maupun maupun ketersediaan komponen pengganti

Sensory Characteristic:penampilan, corak, rasa, daya tarik, bau, selera dan beberapa faktor lainnya mungkin menjadi aspek penting dalam kualitas

Ethical Profile and Image: kualitas adalah bagian terbesar dari kesan pelanggan terhadap produk dan layanan.

Kualitas produk adalah driver kepuasan pelanggan yang multidimensi, Irawan (2009:45). Bagi konsumen, kualitas memiliki beberapa dimensi. Paling tidak, terdapat 6 dimensi dari kualitas produk yang perlu diperhatikan oleh setiap pelaku usaha/produsen yang menginginkan atau mengejar kepuasan pelanggan terhadap kualitas produk. Adapun dimensi kualitas produk menurut Irawan (2009:46-52) yaitu:

\section{Kinerja (Performance)}

Ini adalah dimensi yang paling dasar/basic dan berhubungan dengan fungsi utama suatu produk. Konsumen akan sangat kecewa apabila harapan mereka terhadap dimensi ini tidak terpenuhi. Bagi setiap produk, yang namnya performance bisa berlainan tergantung pada functional value yang disajikan oleh perusahaan.

Keandalan (Reliability)

Dimensi kinerja dan keandalan sepintas terlihat mirip tetapi mempunyai perbedaan yang jelas. Keandalan lebih menunjukkan probabilitas produk gagal menjalankan fungsinya.

Fitur (Feature)

Dimensi ini dapat dikatakan sebagai aspek sekunder. Seperti contoh produk elektronik, fitur-fitur yang diatawarkan dapat dilihat pada menu remote control. Karena perkembangan teknologi, maka fitur menjadi target para perusahaan untuk berinovasi dalam uapaya memuaskankan pelanggan.

Daya Tahan (Durability)

Suatu pengukuran terhadap siklus produk, baik secara teknis maupun waktu. Produk disebut awet kalau sudah banyak digunakan atau sudah lama sekali digunakan. Yang pertama adalah awet secara teknis dan yang kedua awet secara waktu.

Kesesuaian (Conformance)

Dimensi ini menunjukkan seberapa jauh sesuatu produk dapat menyamai standar atau spesifikasi tertentu. Produk yang mempunyai kesesuaian yang tinggi berarti produknya sesuai dengan standar yang telah ditentukan.

Desain (Design)

Dimensi ini adalah dimensi yang unik. Dimensi ini banyak menawarkan aspek emosional dalam mempengaruhi kepuasan pelanggan. Dimensi ini dimasukkan dalam faktor pendorong emosi. 


\section{Kepuasan Pelanggan}

Satisfaction berasal dari bahasa latin, yaitu statis yang berarti enough atau cukup dan facere yang berarti to do atau melakukan. Jadi produk atau jasa yang bisa memuaskan adalah produk atau jasa yang sanggup memberikan sesuatu yang dicari oleh oleh konsumen sampai pada tingkat cukup menurut Irawan dalam Sudaryono (2016:78). Kepuasan adalah respon pemenuhan dari konsumen, dengan kata lain hasil dari penilaian konsumen bahwa produk atau jasa telah memberikan tingkat kenikmatan dimana tingkat pemenuhan ini bisa lebih atau kurang, Sudaryono (2016:78).

Kepuasan konsumen dan loyalitas merek merupakan konsep yang terkait erat dengan jenis perilaku pada tahap pasca pembelian/konsumsi. Rasa puas atau tidak puas terhadap konsumsi suatu produk atau merek adalah hasil evaluasi alternative pasca konumsi atau evaluasi alternative pada tahap kedua, sumarwan(2004 ) dalam Sudaryono (2016:79). Kepuasan akan mendorong konsumen untuk mengulang perilaku pembelian atau konsumsi, Sudaryono (2016:79).

Menurut Irawan (2007) dalam Sudaryono (2016:80) ada sepuluh prinsip kepuasan pelanggan yang harus diperhatikan untuk merebut hati mereka agar dapat memenangkan persaingan, yaitu:

Memulai dengan percaya akan pentingnya kepuasan pelanggan, menanam kepuasan menuai laba.

Memilih pelanggan dengan benar untuk membangun kepuasan pelanggan. Pilihlah pelanggan anda baru kemudian dipuaskan. kunci.

Memahami harapan pelanggan, mengontrol harapan, dan menggali harapan pelanggan adalah

Mencari faktor-faktor yang mempengaruhi kepuasan pelanggan:faktor pendorong, kepuasan dimulai dari pabrik, dimensi kualitas produk, dimensi kualitas pelayanan.

Faktor emosional adalah faktor penting yang mempengaruhi kepuasan pelanggan.

Pelanggan yang complain adalah pelanggan yang loyal. pelanggan.

Garansi kepada pelanggan adalah lompatan yang besar dalam kepuasan konsumen atau

Mendengarkan suara pelanggan melalui pengukuran kepuasan pelanggan.

Peran karyawan sangat penting dalam upaya memuaskan konsumen atau pelanggan

Kepemimpinan adalah teladan kepuasan pelanggan.

Menurut kotler (2009:139) kepuasan adalah perasaan senang atau keceewa seseorang yang muncul setelah membandingkan antara kinerja (hasil) produk yang dipikirkan terhadap terhadap kinerja (hasil) yang diharapkan. Jika kinerja berada dibawah harapan, pelanggan tidak puas. Jika kinerja memenuhi harapan, pelanggan puas.

Untuk menciptakan kepuasan dan loyalitas pelanggan nilai total pelanggan harus lebih besar dari biaya total pelanggan. Kepuasan pembeli akan bergantung kepada kinerja tawaran dalam pemenuhan harapan pembeli. Kepuasan adalah perasaan senang atau kecewa seseorang yang berasal dari perbandingan antara kesannya terhadap kinerja suatu produk dan harapan-harapannya, menurut Buchory dan saladin (2010:67).

Gaspersz (2009:34) mendefinisikan kepuasan pelanggan adalah suatu keadaan dimana kebutuhan, keinginan, dan harapan pelanggan dapat terpenuhi melalui produk yang dikonsumsi.Sehingga kepuasan adalah respon dari perilaku yang ditunjukkan oleh pelanggan dengan membandingkan antara kinerja atau hasil yang dirasakan dengan harapan. Faktor-faktor pendorong kepuasan pelanggan menurut Irawan (2009:37) terdiri dari 5 driver utama yaitu:

Kualitas produk

Pelanggan puas kalau setelah membeli dan menggunakan produk tersebut, ternyta kualitasnya produknya baik.

Harga

Untuk pelanggan yang sensitif, biasanya harga murah adalah sumber kepuasan yang penting karena mereka akan mendapatkan value of money yang tinggi.

Service Quality

Service quality sangat bergantung pada tiga hal yaitu sistem, teknologi dan manusia. Faktor manusia memegang kontribusi sekitar $70 \%$. 
Emotional factor

Kepuasan pelanggan dapat timbul yang berhubungan dengan gaya hidup,rasa percaya diri, rasa bangga dan symbol sukses, bagian dari kelompok penting merupakan bagian dari emotional factor yang mendasari kepuasan pelanggan.

Kemudahan

Pelanggan akan semakin puas apabila relative mudah, nyaman dan efisien dalam mendapatkan produk atau pelayanan.

Untuk menentukan kepuasan pelanggan diperlukan indikator. Adapun indikator untuk kepuasan pelanggan menurut Kotler dan Keller (2009:140) yaitu:

Setia untuk waktu yang lama

Membeli lagi ketika perusahaan memperkenalkan produk baru dan memperbaharui produk lama

Membicarakan hal-hal baik tentang perusahaan

Tidak memperhatikan merek pesaing

Tidak sensitif terhadap harga

Sedangkan menurut Kottler dalam Suwardi (2011) indikator kepuasan pelanggan yaitu:

Re-Purchase: membeli kembali dimana pelanggan tersebut akan kembali kepada perusahaan untuk mencari barang/jasa.

Menciptakan Word of Mouth: dalam hal ini, pelanggan akan mengatakan hal hal yang baik tentang perusahaan kepada orang lain. pesaing.

Menciptakan Citra Merek: Pelanggan akan kurang memperhatikan merek dan iklan dariproduk

Menciptakan keputusan pembelian pada perusahaan yang sama membeli produk lain dari perusahaan yang sama

Menurut Kotler dalam Hurriyati (2010:41 ) ada empat metode yang bisa digunakan untuk mengukur kepuasan pelanggan, yaitu:

Sistem keluhan dan saran

Perusahaan yang memberikan kesempatan penuh bagi pelanggannya untuk menyampaikan pendapat atau bahkan keluhan merupakan perusahaan yang berorientasi pada pelanggan (customer oriented)

Survei kepuasan pelanggan

Sesekali perusahaan perlu melakukan survei kepuasan pelanggan terhadap kualitas jasa tau produk perusahaan tersebut. Survey ini dapat dilakukan dengan penyebaran angket oleh karyawan perusahaan kepada para pelanggan. Melalui survei tersebut perusahaan dapat mengethui kekurangan dan kelebihan produk atau jasa perusahaan tersebut.

Ghost shopping

Metode ini dilaksanakan dengan memperkerjakan beberapa orang perusahaan (ghost shopper) untuk bersikap sebagai pelanggan di perusahaan pesaing, dengan tujuan para ghost shopper tersebut dapat mengetahui kualitas pelayanan perusahaan pesaing sehingga dapat dijadikan sebagai koreksi terhadap kualitas pelayanan perusahaan itu sendiri.

Analisa Pelanggan yang hilang

Metode ini dilakukan perusahaan dengan cara menghubungi kembali pelanggannya yang telah lama tidak berkunjung atau melakukan pembelian lagi di perusahaan tersebut karena telah berpindah ke perusahaan pesaing. Selain itu perusahaan dapat menanyakan sebab -sebab berpindahnya pelanggan ke perusahaan pesaing.

\section{METODE}

\section{Populasi Penelitian}

Populasi dalam penelitian ini adalah pelanggan yang sudah melakukan pembelian minimal dua kali keripik nenas di desa kualu nenas kecamatan tambang kabupten Kampar yang tidak diketahui dengan pasti jumlahnya. Hal ini karena pelanggan yang berbelanja keripik nenas berubah-ubah setiap waktu. Teknik pengambilan sampel apabila populasinya tidak diketahui secara pasti, mengestimasi $\mu$, kita dapat $(1-\alpha) \%$ yakin bahwa eror tidak melebihi nilai e tertentu apabila ukuran sampelnya sebesar $n$, dimana apabila nilai $\sigma$ tidak diketahui, kita dapat menggunakan $\mathrm{s}$ dari sampel sebelumnya ( untuk $\mathrm{n} \geq$ 
30 ) yang memberikan estimasi terhadap $\sigma$, maka standar deviasinya adalah 0,25 . Apabila peneliti ingin menggunakan tingkat presisi 5\%, dan tingkat kepercayaan 95\% dan error estimasi $\mu$ kurang dari 0,05 . Karena $\alpha=0,05$ maka Z0.05 $=1,96$. Sehingga untuk menentukan ukuran sampelnya digunakan persamaan:

$$
\mathrm{n}=\left[\mathrm{Z}_{\alpha / 2} \cdot \sigma / \mathrm{e}\right]^{2}
$$

dimana

$\mathrm{n}=$ Jumlah sampel

$\mathrm{Z}=$ Tingkat kepercayaan yang dipakai adalah $95 \%$ maka nilai $\mathrm{Z}$ yang dipakai adalah 1,96

$\sigma=$ Standar deviasi populasi

$\mathrm{e}=$ Kesalahan sampel yang dikehendaki (sampling error) $5 \%$

Dengan demikian

$$
\begin{aligned}
& \mathrm{n}=[1,962 \times 0,25 / 0,05] 2 \\
& \mathrm{n}=96,04 \\
& \mathrm{n}=96 \text { sampel }
\end{aligned}
$$

Berdasarkan perhitungan diatas maka didapat jumlah sampel sebesar 96. Sehingga dalam penelitian ini jumlah sampel penelitian adalah sebanyak 96 pelanggan. Teknik pengambilan sampel dalam penelitian ini menggunakan purposive sampling yaitu teknik pengambilan sampel secara sengaja dengan persyaratan sampel yang diperlukan. Pelanggan yang telah melakukan minimal 2 kali pembelian/mengkonsumsi keripik Nenas di Desa Kualu Nenas.

\section{Persamaan Regresi Linier Berganda}

Analisis regresi linier berganda digunakan untuk mengetahui pengaruh antara dua atau lebih variabel independen dengan satu variabel dependen, yang ditampilkan dalam bentuk persamaan regresi , Priyatno (2016:92). Adapun bentuk persamaan regresi linier berganda yaitu: $\mathrm{Y}=\mathrm{a}+\mathrm{b}_{1} \mathrm{X}_{1}+\mathrm{b}_{2} \mathrm{X}_{2}+\mathrm{b}_{3} \mathrm{X}_{3}+\mathrm{b}_{4} \mathrm{X}_{4}+\mathrm{b}_{5} \mathrm{X}_{5}+\mathrm{b}_{6} \mathrm{X}_{6}$

Dimana

$$
\begin{array}{ll}
\mathrm{Y} & =\text { Kepuasan Pelanggan } \\
\mathrm{a} & =\text { konstanta } \\
\mathrm{X} 1 & =\text { Kinerja } \\
\mathrm{X} 2 & =\text { Kehandalan } \\
\mathrm{X} 3 & =\text { Fitur } \\
\mathrm{X} 4 & =\text { Daya Tahan } \\
\mathrm{X} 5 & =\text { Kesesuaian } \\
\mathrm{X} 6 & =\text { Desain } \\
\mathrm{b} 1 \ldots \mathrm{b} 6 & =\text { Koefisien regresi }
\end{array}
$$

\section{Pengujian Hipotesis}

Uji F

Uji F digunakan untuk mengetahui apakah variabel independen secara bersama-sama berpengaruh terhadap variabel independen atau tidak, menurut Priyatno (2016:99). Uji F mempunyai kriteria sebagai berikut:

Jika F hitung $\leq \mathrm{F}$ tabel maka $\mathrm{H} 0$ diterima dan Ha ditolak

Jika $\mathrm{F}$ hitung $\geq \mathrm{F}$ tabel maka $\mathrm{H} 0$ ditolak dan Ha diterima

Uji t

Menurut Priyatno (2016:91) uji t digunakan untuk mengetahui pengaruh secara signifikan antara variabel independen terhadap variabel dependen. Nilai t yang diperoleh dari hasilperhitungan dibandingkan dengan nilai yang terdapat pada t tabel dengan tingkat signifikansi sebesar $5 \%$. Uji t dikatakan bermakna apabila:

Jika t hitung $\leq \mathrm{t}$ tabel maka H0 diterima dan Ha ditolak

Jika t hitung $\geq \mathrm{t}$ tabel maka Ha diterima dan $\mathrm{H} 0$ ditolak 


\section{HASIL DAN PEMBAHASAN}

\section{Persamaan Regresi Linier Berganda}

Dengan menggunakan Program SPSS for Windows versi 24.0, didapat koefisien pada persamaan Regresi Linier Berganda, yang terlihat pada tabel 1.

Tabel 1. Analisis Regresi Linier Berganda

Coefficients $^{\mathrm{a}}$

\begin{tabular}{|c|c|c|c|c|c|c|}
\hline \multirow{2}{*}{\multicolumn{2}{|c|}{ Model }} & \multicolumn{2}{|c|}{ Unstandardized Coefficients } & $\begin{array}{l}\text { Standardized } \\
\text { Coefficients }\end{array}$ & \multirow[b]{2}{*}{$\mathrm{t}$} & \multirow[b]{2}{*}{ Sig. } \\
\hline & & $\mathrm{B}$ & Std. Error & Beta & & \\
\hline 1 & (Constant) & 16.089 & 4.496 & & 3.578 & .001 \\
\hline & Kinerja (X1) & .186 & .283 & .070 & .656 & .513 \\
\hline & Kehandalan(X2) & 270 & 229 & 160 & 1.175 & 243 \\
\hline & Fitur (X3) & .451 & 224 & 244 & 2.009 & .048 \\
\hline & Daya Tahan $(\mathrm{X} 4)$ & 167 & .332 & .063 & .503 & .616 \\
\hline & Kesesuaian (X5) & .011 & .232 & .004 & .049 & .961 \\
\hline & Desain (X6) & .458 & .143 & .329 & 3.208 & .002 \\
\hline
\end{tabular}

a. Dependent Variable: Kepuasan Pelanggan

Sumber: Data diolah

Berdasarkan tabel 1 maka diperoleh persamaan regresi linier berganda untuk mengetahui pengaruh kualitas produk terhadap kepuasan pelanggan keripik nenas sebagai berikut:

$\mathrm{Y}=\mathrm{a}+\mathrm{b}_{1} \mathrm{X}_{1}+\mathrm{b}_{2} \mathrm{X}_{2}+\mathrm{b}_{3} \mathrm{X}_{3}+\mathrm{b}_{4} \mathrm{X}_{4}+\mathrm{b}_{5} \mathrm{X}_{5}+\mathrm{b}_{6} \mathrm{X}_{6}$

Dimana

$\mathrm{Y} \quad=$ Kepuasan Pelanggan

$\mathrm{X}_{1} \quad=$ Kinerja

$\mathrm{X}_{2} \quad=$ Kehandalan

$\mathrm{X}_{3} \quad=$ Fitur

$\mathrm{X}_{4} \quad=$ Daya Tahan

$\mathrm{X}_{5} \quad=$ Kesesuaian

$\mathrm{X}_{6} \quad=$ Desain

a $\quad=$ Intersep

b1-b7 = Koefisien regresi variabel bebas

Adapun persamaan regresi linier bergandanya yaitu:

$\mathrm{Y}=16,089+0,186 \mathrm{X} 1+0,270 \mathrm{X} 2+0,451 \mathrm{X} 3+0,167 \mathrm{X} 4+0,011 \mathrm{X} 5+0,458 \mathrm{X} 6$

Arti Persamaan regresi linier berganda tersebut yaitu:

Nilai a $=16,089$ menunjukkan bahwa apabila kinerja, kehandalan, fitur, daya tahan, kesesuaian dan desain nol maka kepuasan pelanggan keripik nenas di Desa Kualu Nenas Kecamatan Tambang Kabupaten Kampar Provinsi Riau sebesar 16,089.

Nilai b1 $=0,186$ menunjukkan apabila nilai variabel kinerja (X1) naik 1 satuan maka kepuasan pelanggan keripik nenas di Desa Kualu Nenas Kecamatan Tambang Kabupaten Kampar Provinsi Riau akan naik sebesar 0,186 satuan dengan asumsi variabel X2, X3, X4, X5,dan X6 tetap atau konstan

Nilai b2 $=0,270$ menunjukkan apabila nilai variabel kehandalan $(X 2)$ naik 1 satuan maka kepuasan pelanggan keripik nenas di Desa Kualu Nenas Kecamatan Tambang Kabupaten Kampar Provinsi Riau akan naik sebesar 0,270 satuan dengan asumsi variabel X1, X3, X4, X5,dan X6 tetap atau konstan

Nilai b3 $=0,451$ menunjukkan apabila nilai variabel fitur (X3) naik 1 satuan maka kepuasan pelanggan keripik nenas di Desa Kualu Nenas Kecamatan Tambang Kabupaten Kampar Provinsi Riau akan naik sebesar 0,451 satuan dengan asumsi variabel X1, X2, X4, X5, dan X6 tetap atau konstan.

Nilai b4 $=0,167$ menunjukkan apabila nilai variabel daya tahan $(X 4)$ naik 1 satuan maka kepuasan pelanggan keripik nenas di Desa Kualu Nenas Kecamatan Tambang Kabupaten Kampar 
Provinsi Riau akan naik sebesar 0,167 satuan dengan asumsi variabel X1, X2, X3, X5, dan X6 tetap atau konstan.

Nilai b5 $=0,011$ menunjukkan apabila nilai variabel kesesuaian (X5) naik 1 satuan maka kepuasan pelanggan keripik nenas di Desa Kualu Nenas Kecamatan Tambang Kabupaten Kampar Provinsi Riau akan naik sebesar 0,011 satuan dengan asumsi variabel X1, X2, X3, X4,dan X6 tetap atau konstan.

Nilai b6 = 0,458 menunjukkan apabila nilai variabel desain (X6) naik 1 satuan maka kepuasan pelanggan keripik nenas di Desa Kualu Nenas Kecamatan Tambang Kabupaten Kampar Provinsi Riau akan naik sebesar 0,458 satuan dengan asumsi variabel X1, X2, X3, X4,dan X5 tetap atau konstan.

\section{Koefisien Determinasi}

Koefisien Determinasi menunjukkan persentase sumbangan pengaruh variabel bebas (kualitas produk) secara bersama-sama terhadap variabel terikat (kepuasan pelanggan). Besarnya koefisien Determinasi dapat dilihat pada tabel 2

Tabel 2. Model Summaryb

Model Summary

\begin{tabular}{crrrrr}
\hline Model & R & R Square & Adjusted R Square & Std. Error of the Estimate \\
\hline 1 & $.760^{\mathrm{a}}$ & .577 & .549 & & 6.045 \\
\hline
\end{tabular}

a. Predictors: (Constant), Desain (X6), Kesesuaian (X5), Kinerja (X1), Fitur (X3), Daya Tahan (X4), Kehandalan $(\mathrm{X} 2)$

b. Dependent Variable: Kepuasan Pelanggan

Sumber: Data diolah

Berdasarkan tabel 2 diketahui semua variabel bebas yaitu variabel kinerja, kehandalan, fitur, daya tahan, kesesuaian dan desain mempunyai hubungan dengan variabel terikat kepuasan pelanggan, hal ini dibuktikan dengan nilai koefisien korelasi berganda $\mathrm{R}$ sebesar 0,760 . Dan nilai koefisen determinasi berganda Adjusted R Square sebesar 0,549. Ini menunjukkan bahwa keenam variabel bebas (kualitas produk) tersebut bersama-sama memberikan sumbangan pengaruh terhadap kepuasan pelanggan keripik nenas di Desa Kualu Nenas Kecamatan Tambang Kabupaten Kampar Provinsi Riau sebesar 54,90\%. Sedangkan sisanya dipengaruhi oleh variabel lain yang tidak diamati dalam penelitian ini.

\section{Uji Anova}

Uji F pada dasarnya menunjukkan apakah semua variabel bebas yaitu variabel kinerja, kehandalan, fitur, daya tahan, kesesuaian dan desain mempunyai pengaruh signifikan terhadap kepuasan pelanggan keripik nenas di Desa Kualu Nenas Kecamatan Tambang Kabupaten Kampar Provinsi Riau. Sebelum melakukan pengujian dilakukan perumusan hipotesis yaitu:

Ho = Kinerja, kehandalan, fitur, daya tahan, kesesuaian, dan desain secara simultan tidak mempunyai pengaruh terhadap kepuasan pelanggan keripik nenas di Desa Kualu Nenas Kecamatan Tambang Kabupaten Kampar Provinsi Riau.

$\mathrm{H}_{7} \quad=$ Kinerja, kehandalan, fitur, daya tahan, kesesuaian, dan desain secara simultan mempunyai pengaruh terhadap kepuasan pelanggan keripik nenas di Desa Kualu Nenas Kecamatan Tambang Kabupaten Kampar Provinsi Riau.

Ho diterima apabila $\mathrm{F}$ hitung kecil atau sama dengan $\mathrm{F}$-tabel dan $\mathrm{H}_{7}$ diterima apabila F-hitung lebih besar dari F tabel. Dengan menggunakan program SPSS for Windows versi 24.0 diperoleh uji F seperti pada tabel 3

Tabel 3. Anova

ANOVA $^{\mathrm{a}}$

\begin{tabular}{llllll}
\hline Model & Sum of Squares & Df & Mean Square & F & Sig. \\
\hline 1 Regression & 4437.981 & 6 & 739.663 & 20.243 & $.000^{\mathrm{b}}$ \\
$\quad$ Residual & 3252.019 & 89 & 36.540 & & \\
$\quad$ Total & 7690.000 & 95 & & & \\
\hline
\end{tabular}

a. Dependent Variable: Kepuasan Pelanggan 
b. Predictors: (Constant), Desain (X6), Kesesuaian (X5), Kinerja (X1), Fitur (X3), Daya Tahan (X4), Kehandalan(X2)

Sumber: Data diolah

Berdasarkan tabel 3 nilai F hitung sebesar 20,243. Sedangkan F tabel pada tingkat keyakinan ( $\alpha$ ) $5 \%$ dengan derajat bebas pembilang

$=(\mathrm{k}-1):(\mathrm{n}-\mathrm{k})$

$=(7-1):(96-7)$

$=6: 89$

$=2,20$

Dengan membandingkan hasil $\mathrm{F}$ tabel dengan $\mathrm{F}$ hitung, menunjukkan bahwa $\mathrm{F}$ hitung lebih besar dari F tabel, yaitu 20,243 >2,2. Hal ini menunjukkan bahwa kinerja, kehandalan, fitur, daya tahan, kesesuaian, dan desain secara simultan mempunyai pengaruh terhadap kepuasan pelanggan keripik nenas di Desa Kualu Nenas Kecamatan Tambang Kabupaten Kampar Provinsi Riau.

Uji t

Uji t digunakan untuk menguji pengaruh variabel bebas terhadap variabel terikat secara individual. Ho diterima apabila nilai t hitung lebih kecil atau sama dengan $\mathrm{t}$ tabel. Dan $\mathrm{H}_{1}$ diterima apabila $t$ hitung lebih besar dari $t$ tabel. Adapun hasil pengujian parsial untuk masing-masing variabel bebas:

Pengaruh kinerja terhadap kepuasan pelanggan keripik nenas di desa kualu nenas di Desa Kualu Nenas Kecamatan Tambang Kabupaten Kampar Provinsi Riau.

Ho : Kinerja tidak berpengaruh secara signifikan terhadap kepuasan pelanggan keripik nenas di Desa Kualau Nenas Kecamatan Tambang Kabupaten Kampar Provinsi Riau

$\mathrm{H}_{1}$ : Kinerja berpengaruh secara signifikan terhadap kepuasan pelanggan keripik nenas di Desa Kualau Nenas Kecamatan Tambang Kabupaten Kampar Provinsi Riau.

Tabel 4. Uji t

Coefficients $^{\mathrm{a}}$

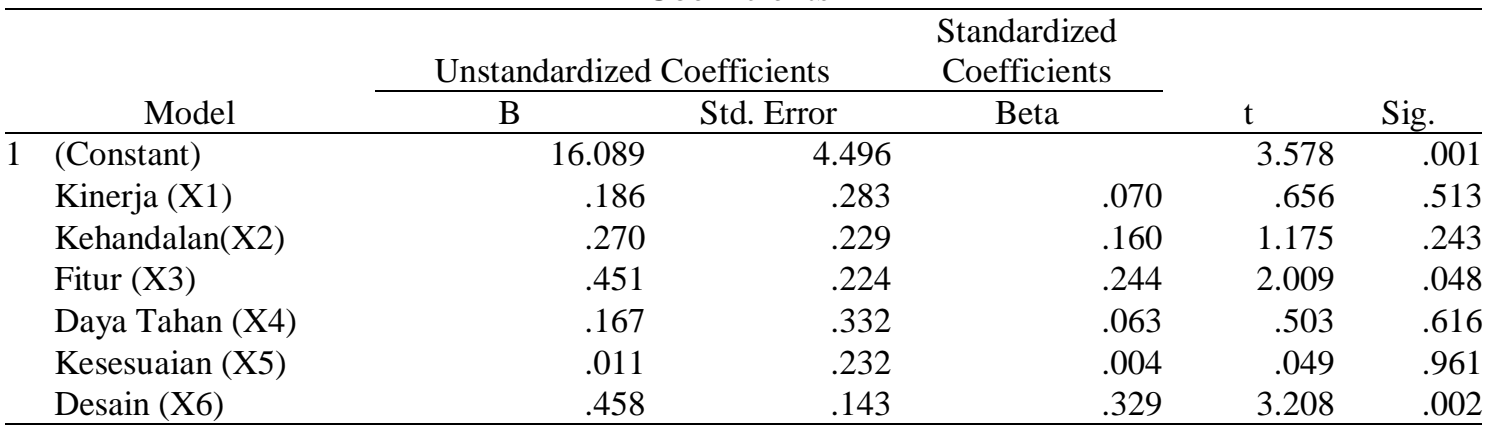

a. Dependent Variable: Kepuasan Pelanggan

Sumber: Data diolah

Nilai t hitung kinerja (X1) yaitu 0,656 dengan t tabel 1,98698 dengan taraf signifikasi 0,513. Hal ini menunjukkan Ho diterima dan H1 ditolak sehingga kinerja (X1) tidak berpengaruh secara signifikan terhadap kepuasan pelanggan keripik nenas di Desa Kualu Nenas Kecamatan Tambang Kabupaten Kampar Provinsi Riau.

Pengaruh kehandalan terhadap kepuasan pelanggan keripik nenas di desa kualu nenas kecamatan tambang kabupaten Kampar Provinsi Riau

Ho : Kehandalan tidak berpengaruh secara signifikan terhadap kepuasan pelanggan keripik nenas di Desa Kualau Nenas Kecamatan Tambang Kabupaten Kampar Provinsi Riau

$\mathrm{H}_{2} \quad$ : Kehandalan berpengaruh secara signifikan terhadap kepuasan pelanggan keripik nenas di Desa Kualau Nenas Kecamatan Tambang Kabupaten Kampar Provinsi Riau

Nilai t hitung kehandalan $\left(\mathrm{X}_{2}\right)$ yaitu 1,175 dengan $\mathrm{t}$ tabel 1,98698 dengan taraf signifikasi 0,243.

Hal ini menunjukkan $\mathrm{H}_{\mathrm{o}}$ diterima dan $\mathrm{H}_{2}$ ditolak sehingga kehandalan $\left(\mathrm{X}_{2}\right)$ tidak berpengaruh secara signifikan terhadap kepuasan pelanggan keripik nenas di Desa Kualu Nenas Kecamatan Tambang Kabupaten Kampar Provinsi Riau. 
Pengaruh fitur terhadap kepuasan pelanggan keripik nenas di desa kualu nenas kecamatan tambang kabupaten Kampar Provinsi Riau

Ho : Fitur tidak berpengaruh secara signifikan terhadap kepuasan pelanggan keripik nenas di Desa Kualau Nenas Kecamatan Tambang Kabupaten Kampar Provinsi Riau.

$\mathrm{H}_{3} \quad$ : Fitur berpengaruh secara signifikan terhadap kepuasan pelanggan keripik nenas di Desa Kualau Nenas Kecamatan Tambang Kabupaten Kampar Provinsi Riau.

Nilai t hitung fitur $\left(\mathrm{X}_{3}\right)$ yaitu 2,009 dengan $\mathrm{t}$ tabel 1,98698 dengan taraf signifikasi 0,048. Hal ini menunjukkan $\mathrm{H}_{\mathrm{o}}$ ditolak dan $\mathrm{H}_{3}$ diterima sehingga fitur $\left(\mathrm{X}_{3}\right)$ berpengaruh secara signifikan terhadap kepuasan pelanggan keripik nenas di Desa Kualu Nenas Kecamatan Tambang Kabupaten Kampar Provinsi Riau.

Pengaruh daya tahan terhadap kepuasan pelanggan keripik nenas di desa kualu nenas kecamatan tambang kabupaten Kampar Provinsi Riau

Ho : Daya tahan tidak berpengaruh secara signifikan terhadap kepuasan pelanggan keripik nenas di Desa Kualau Nenas Kecamatan Tambang Kabupaten Kampar Provinsi Riau.

$\mathrm{H}_{4} \quad$ : Daya tahan berpengaruh secara signifikan terhadap kepuasan pelanggan keripik nenas di Desa Kualau Nenas Kecamatan Tambang Kabupaten Kampar Provinsi Riau.

Nilai t hitung daya tahan (X4) yaitu 0,503 dengan t tabel 1,98698 dengan taraf signifikasi 0,616. Hal ini menunjukkan Ho diterima dan H4 ditolak sehingga daya tahan (X4) tidak berpengaruh secara signifikan terhadap kepuasan pelanggan keripik nenas di Desa Kualu Nenas Kecamatan Tambang Kabupaten Kampar Provinsi Riau.

Pengaruh kesesuaian terhadap kepuasan pelanggan keripik nenas di desa kualu nenas kecamatan tambang kabupaten Kampar Provinsi Riau

Ho : Kesesuaian tidak berpengaruh secara signifikan terhadap kepuasan pelanggan keripik nenas di Desa Kualau Nenas Kecamatan Tambang Kabupaten Kampar Provinsi Riau

$\mathrm{H}_{5} \quad$ : Kesesuaian berpengaruh secara signifikan terhadap kepuasan pelanggan keripik nenas di Desa Kualau Nenas Kecamatan Tambang Kabupaten Kampar Provinsi Riau

Nilai t hitung kesesuaian (X5) yaitu 0,049 dengan t tabel 1,98698 dengan taraf signifikasi 0,961. Hal ini menunjukkan Ho diterima dan H5 ditolak sehingga kesesuaian (X5) tidak berpengaruh secara signifikan terhadap kepuasan pelanggan keripik nenas di Desa Kualu Nenas Kecamatan Tambang Kabupaten Kampar Provinsi Riau.

Pengaruh desain terhadap kepuasan pelanggan keripik nenas di desa kualu nenas kecamatan Tambang Kabupaten Kampar Provinsi Riau

Ho : Desain tidak berpengaruh secara signifikan terhadap kepuasan pelanggan keripik

nenas di Desa Kualau Nenas Kecamatan Tambang Kabupaten Kampar Provinsi Riau

$\mathrm{H}_{6} \quad$ : Desain berpengaruh secara signifikan terhadap kepuasan pelanggan keripik nenas di Desa

Kualau Nenas Kecamatan Tambang Kabupaten Kampar Provinsi Riau

Nilai t hitung desain (X6) yaitu 3,208 dengan t tabel 1,98698 dengan taraf signifikasi 0,002. Hal ini menunjukkan Ho ditolak dan H1 diterima sehingga desain (X6) berpengaruh secara signifikan terhadap kepuasan pelanggan keripik nenas di Desa Kualu Nenas Kecamatan Tambang Kabupaten Kampar Provinsi Riau.

Dari hasil uji statistik tersebut hanya variabel fitur $\left(\mathrm{X}_{3}\right)$ dan desain $\left(\mathrm{X}_{6}\right)$ yang berpengaruh secara parsial terhadap kepuasan pelanggan keripik nenas di Desa Kualau Nenas Kecamatan Tambang Kabupaten Kampar Provinsi Riau.

Pengaruh Kualitas Produk terhadap Kepuasan Pelanggan Keripik Nenas di Desa Kualu Nenas Kecamatan Tambang Kabupaten Kampar Provinsi Riau

Berdasarkan hasil penelitian yang dilakukan oleh Yetty Husnul Hayati dan Gracia Sekartaji dalam JIMFE (Jurnal Ilmiah Manajemen Fakultas Ekonomi) Volume 1 No. 1 Tahun 2015, Hal. 49-56 (2015) dengan E-ISSN 2502-5678, dengan judul Pengaruh Kualitas Produk Terhadap Kepuasan Pelanggan di Restoran Bebek dan Ayam Goreng Pak Ndut Solo, mengemukakan bahwa kualitas produk secara bersama-sama mempengaruhi kepuasan. Hal ini diperoleh berdasarkan nilai $\mathrm{F}$ hitung $>\mathrm{F}$ tabel yaitu 89,621 > 1,96. Serta tingkat signifikan angka (probabilitas Sig.) sebesar 0,000, dimana $0,000<\alpha 0,05$. Sehingga hal ini menunjukkan bahwa kualitas produk secara bersama-sama 
berpengaruh signifikan terhadap kepuasan Pelanggan di Restoran Bebek dan Ayam Goreng Pak Ndut Solo.

Begitu juga dengan penelitian yang dilakukan oleh Suryari Purnama dan Rizki Sandrini dalam Forum Ilmiah Volume 9 Nomer 2, Mei 2012, dengan judul Analisis Pengaruh Kualitas Produk terhadap Kepuasan Konsumen Tas Sophie Paris, menghasilkan bahwa kualitas produk secara bersamasama mempengaruhi kepuasan. Hal ini diperoleh berdasarkan nilai Sig F yaitu 0,000 < 0,05, dengan bantuan SPSS versi 13.0. Sehingga hal ini menunjukkan bahwa kualitas produk secara bersama-sama berpengaruh signifikan terhadap kepuasan konsumen Tas Sophie Paris.

Berdasarkan hasil penelitian menunjukkan bahwa variabel bebas yaitu Kinerja (X1), Kehandalan (X2), Fitur (X3), Daya Tahan (X4), Kesesuaian (X5), dan Desain (X6) berpengaruh secara simultan terhadap kepuasan pelanggan (Y) keripik nenas di Desa Kualu Nenas Kecamaan Tambang Kabupaten Kampar Provinsi Riau. Hal ini ditunjukkan dari nilai F hitung lebih besar dari F tabel yaitu 20,243 dengan signifikansi 0,000. Sehingga dapat dikatakan bahwa Kinerja $\left(X_{1}\right)$, Kehandalan $\left(X_{2}\right)$, Fitur $\left(X_{3}\right)$, Daya Tahan $\left(\mathrm{X}_{4}\right)$, Kesesuaian $\left(\mathrm{X}_{5}\right)$, dan Desain $\left(\mathrm{X}_{6}\right)$ berpengaruh secara simultan terhadap kepuasan pelanggan (Y) keripik nenas di Desa Kualu Nenas Kecamaan Tambang Kabupaten Kampar Provinsi Riau.

Hal ini sesuai juga dengan teori yang dikemukakan bahwa kualitas produk adalah driver kepuasan pelanggan yang multidimensi, Irawan (2009:45). Menurut Irawan (2007) dalam Sudaryono (2016:80) ada sepuluh prinsip kepuasan pelanggan yang harus diperhatikan untuk merebut hati mereka agar dapat memenangkan persaingan, salah satunya adalah mencari faktor-faktor yang mempengaruhi kepuasan pelanggan yaitu faktor pendorong, kepuasan dimulai dari pabrik, dimensi kualitas produk, dimensi kualitas pelayanan.

Oleh karena itu dapat disimpulkan apabila kualitas produk kerpik nenas diperbaiki, ditingkatkan, dikelola dengan baik dari segi kinerja, kehandalan, fitur, daya tahan, kesesuaian, dan desain maka akan meningkatkan kepuasan pelanggan keripik nenas yang dihasilkan di Desa Kualu Nenas Kecamatan Tambang Kabupaten Kampar Provinsi Riau.

\section{Pengaruh Kinerja $\left(\mathrm{X}_{1}\right)$ terhadap Kepuasan Pelanggan}

Berdasarkan hasil penelitian menunjukkan bahwa variabel Kinerja (X1) secara parsial tidak berpengaruh signifikan terhadap kepuasan pelanggan keripik nenas di Desa Kualu Nenas Kecamatan Tambang Kabupaten Kampar Provinsi Riau. Hal ini diketahui dari nilai t hitung Kinerja (X1) lebih kecil dari t tabel yaitu $0,656<1,98698$ dan taraf signifikansi $0,513>0,05$. Hal ini menyebabkan Ho diterima dan H1 ditolak sehingga Kinerja (X1) tidak berpengaruh secara signifikan terhadap kepuasan pelanggan keripik nenas di Desa Kualu Nenas Kecamatan Tambang Kabupaten Kampar Provinsi Riau.

Dari hasil penelitian tersebut dapat disimpulkan bahwa Kinerja (X1) tidak berpengaruh terhadap kepuasan pelanggan keripik nenas di Desa Kualu Nenas Kecamatan Tambang Kabupaten Kampar Provinsi Riau. Hal ini berdasarkan angket dari penyataan keripik nenas mudah ditemukan di supermarket memiliki skor terendah yaitu 2,99, kondisi ini menunjukkan bahwa keripik nenas hasil Desa Kualu Nenas, jarang ditemui di supermarket. Pelaku usaha keripik nenas lebih cenderung memasarkan keripik nenas hanya di sepanjang jalan daerah Desa Kualu Nenas. Akibatnya, produk keripik nenas kurang dikenal oleh masyarakat luas. Sementara dari hasil angket pernyataan keripik nenas dapat dijadikan oleh-oleh mendapat skor tertinggi 4,24 dengan kriteria sangat baik.

\section{Pengaruh Kehandalan $\left(\mathbf{X}_{2}\right)$ terhadap Kepuasan Pelanggan}

Berdasarkan hasil penelitian menunjukkan bahwa variabel Kehandalan (X2) secara parsial tidak berpengaruh signifikan terhadap kepuasan pelanggan keripik nenas di Desa Kualu Nenas Kecamatan Tambang Kabupaten Kampar Provinsi Riau. Hal ini diketahui dari nilai t hitung Kehandalan (X2) lebih kecil dari t tabel yaitu $1,175<1,98698$ dan taraf signifikansi $0,243>0,05$. Hal ini menyebabkan Ho diterima dan $\mathrm{H} 2$ ditolak sehingga Kehandalan (X2) tidak berpengaruh secara signifikan terhadap kepuasan pelanggan keripik nenas di Desa Kualu Nenas Kecamatan Tambang Kabupaten Kampar Provinsi Riau.

Dari hasil penelitian tersebut dapat disimpulkan bahwa Kehandalan (X2) tidak berpengaruh terhadap kepuasan pelanggan keripik nenas di Desa Kualu Nenas Kecamatan Tambang Kabupaten Kampar Provinsi Riau. Hal ini berdasarkan angket dari penyataan bentuk keripik nenas menggugah selera memiliki skor terendah yaitu 2,55, hal ini menunjukkan bahwa bentuk keripik nenas hasil Desa 
Kualu Nenas tidak menarik. Hal ini terlihat secara jelas (plastik transparan) antara potongan satu dengan potongan yang lain tidak sama ukurannya, warna keripik nenas tidak merata ada yang kuning pucat, kuning tua dan kecoklatan. Pelaku usaha keripik nenas lebih cenderung menggunakan bahan mentah keripik nenas dari buah nenas yang sudah tidak segar dan tingkat kematangan buah nenas yang sudah tinggi. Akibatnya, hasil produk keripik nenas tidak menarik dilihat dari segi bentuknya. Sementara dari hasil angket pernyataan rasa keripik nenas enak mendapat skor tertinggi 3,85 dengan kriteria baik.

\section{Pengaruh Fitur $\left(\mathbf{X}_{3}\right)$ terhadap Kepuasan Pelanggan}

Berdasarkan hasil penelitian menunjukkan bahwa variabel Fitur (X3) secara parsial berpengaruh signifikan terhadap kepuasan pelanggan keripik nenas di Desa Kualu Nenas Kecamatan Tambang Kabupaten Kampar Provinsi Riau. Hal ini diketahui dari nilai t hitung Fitur (X3) lebih besar dari t tabel yaitu 2,009 < 1,98698 dan taraf signifikansi 0,048 < 0,05. Hal ini menyebabkan Ho ditolak dan H1 diterima sehingga Fitur (X3) berpengaruh secara signifikan terhadap kepuasan pelanggan keripik nenas di Desa Kualu Nenas Kecamatan Tambang Kabupaten Kampar Provinsi Riau.

Dari hasil penelitian tersebut dapat disimpulkan bahwa Fitur (X3) berpengaruh terhadap kepuasan pelanggan keripik nenas di Desa Kualu Nenas Kecamatan Tambang Kabupaten Kampar Provinsi Riau. Hal ini berdasarkan angket dari penyataan rasa keripik nenas beraneka bentuk memiliki skor terendah yaitu 2,91 dengan kriteria cukup. Hal ini menunjukkan bahwa rasa keripik nenas dari Desa Kualu Nenas tidak bervariasi, sementara rasa dari keripik nenas hanya murni dari rasa buah nenas asli (manis atau asam), sehingga tidak semua orang menyukai keripik nenas. Sementara dari hasil angket pernyataan keripik nenas mampu bersaing dengan produk lain memiliki skor 3,69 dengan kriteria baik.

\section{Pengaruh Daya Tahan $\left(\mathbf{X}_{4}\right)$ terhadap Kepuasan Pelanggan}

Berdasarkan hasil penelitian menunjukkan bahwa variabel Daya Tahan (X4) secara parsial tidak berpengaruh signifikan terhadap kepuasan pelanggan keripik nenas di Desa Kualu Nenas Kecamatan Tambang Kabupaten Kampar Provinsi Riau. Hal ini diketahui dari nilai t hitung Daya Tahan (X4) lebih kecil dari t tabel yaitu 0,503 <1,98698 dan taraf signifikansi 0,616 >0,05. Hal ini menyebabkan Ho diterima dan H4 ditolak sehingga Daya Tahan (X4) tidak berpengaruh secara signifikan terhadap kepuasan pelanggan keripik nenas di Desa Kualu Nenas Kecamatan Tambang Kabupaten Kampar Provinsi Riau.

Dari hasil penelitian tersebut dapat disimpulkan bahwa Daya Tahan (X4) tidak berpengaruh terhadap kepuasan pelanggan keripik nenas di Desa Kualu Nenas Kecamatan Tambang Kabupaten Kampar Provinsi Riau. Hal ini berdasarkan angket dari penyataan keripik nenas mencantumkan tanggal kadarluarsa memiliki skor terendah yaitu 2,39 dengan kategori cukup. hal ini menunjukkan bahwa produk keripik nenas belum memenuhi syarat tidak mencatumkan batas waktu konsumsi. Hal ini terlihat secara jelas pada kemasan keripik nenas tidak terdapat tanggal kadarluarsa. Sementara dari hasil angket pernyataan keripik nenas garing mendapat skor tertinggi 3,48 dengan kriteria baik.

\section{Pengaruh Kesesuaian $\left(\mathbf{X}_{5}\right)$ terhadap Kepuasan Pelanggan}

Berdasarkan hasil penelitian menunjukkan bahwa variabel Kesesuaian (X5) secara parsial tidak berpengaruh signifikan terhadap kepuasan pelanggan keripik nenas di Desa Kualu Nenas Kecamatan Tambang Kabupaten Kampar Provinsi Riau. Hal ini diketahui dari nilai t hitung Kesesuaian (X5) lebih kecil dari t tabel yaitu 0,049 < 1,98698 dan taraf signifikansi 0,961 >0,05. Hal ini menyebabkan Ho diterima dan H5 ditolak sehingga Kesesuaian (X5) tidak berpengaruh secara signifikan terhadap kepuasan pelanggan keripik nenas di Desa Kualu Nenas Kecamatan Tambang Kabupaten Kampar Provinsi Riau.

Dari hasil penelitian tersebut dapat disimpulkan bahwa Kesesuaian (X5) tidak berpengaruh terhadap kepuasan pelanggan keripik nenas di Desa Kualu Nenas Kecamatan Tambang Kabupaten Kampar Provinsi Riau. Hal ini berdasarkan angket dari penyataan keripik nenas lulus uji MUI memiliki skor terendah yaitu 3,07 dengan kriteria cukup. Hal ini terlihat secara jelas pada kemasan keripik nenas tidak ditemui label halal dari MUI. Sementara dari hasil angket pernyataan keripik nenas berbahan baku halal mendapat skor tertinggi 3,73 dengan kriteria baik. 


\section{Pengaruh Desain $\left(\mathbf{X}_{6}\right)$ terhadap Kepuasan Pelanggan}

Berdasarkan hasil penelitian menunjukkan bahwa variabel Desain (X6) secara parsial tidak berpengaruh signifikan terhadap kepuasan pelanggan keripik nenas di Desa Kualu Nenas Kecamatan Tambang Kabupaten Kampar Provinsi Riau. Hal ini diketahui dari nilai t hitung Desain (X6) lebih kecil dari t tabel yaitu 3,208 $<1,98698$ dan taraf signifikansi 0,002 < 0,05. Hal ini menyebabkan Ho ditolak dan H1 diterima sehingga Desain (X6) berpengaruh secara signifikan terhadap kepuasan pelanggan keripik nenas di Desa Kualu Nenas Kecamatan Tambang Kabupaten Kampar Provinsi Riau.

Dari hasil penelitian tersebut dapat disimpulkan bahwa Desain (X6) berpengaruh terhadap kepuasan pelanggan keripik nenas di Desa Kualu Nenas Kecamatan Tambang Kabupaten Kampar Provinsi Riau. Hal ini berdasarkan angket dari penyataan kemasan keripik nenas dapat digunakan kembali bentuk keripik memiliki skor terendah yaitu 2,03 dengan kriteria kurang baik. Hal ini menunjukkan bahwa kemasan keripik nenas hasil Desa Kualu Nenas tidak dapat digunakan kembali. Hal ini terlihat secara jelas (plastik transparan) yang digunakan penyimpanan keripik nenas siap pasar. Sementara dari hasil angket pernyataan kemasan keripik nenas sesuai standar mendapat skor tertinggi 3,42 dengan kriteria baik.

\section{SIMPULAN}

Berdasarkan pada uraian bab terdahulu, maka pada bab ini berisi kesimpulan dan saran penelitian yaitu:

Variabel kinerja tidak berpengaruh signifikan terhadap kepuasan pelanggan keripik nenas di Desa Kualu Nenas Kecamatan Tambang Kabupaten Kampar Provinsi Riau.

Variabel kehandalan tidak berpengaruh signifikan terhadap kepuasan pelanggan keripik nenas di Desa Kualu Nenas Kecamatan Tambang Kabupaten Kampar Provinsi Riau.

Variabel fitur berpengaruh signifikan terhadap kepuasan pelanggan keripik nenas di Desa Kualu Nenas Kecamatan Tambang Kabupaten Kampar Provinsi Riau.

Variabel daya tahan tidak berpengaruh signifikan parsial terhadap kepuasan pelanggan keripik nenas di Desa Kualu Nenas Kecamatan Tambang Kabupaten Kampar Provinsi Riau.

Variabel kesesuaian tidak berpengaruh signifikan secara terhadap kepuasan pelanggan keripik nenas di Desa Kualu Nenas Kecamatan Tambang Kabupaten Kampar Provinsi Riau.

Variabel desain berpengaruh signifikan terhadap kepuasan pelanggan keripik nenas di Desa Kualu Nenas Kecamatan Tambang Kabupaten Kampar Provinsi Riau.

Kualitas produk yang terdiri dari kinerja, kehandalan, fitur, daya tahan, kesesuaian, dan desain berpengaruh secara simultan terhadap kepuasan pelanggan keripik nenas di Desa Kualu Nenas Kecamatan Tambang Kabupaten Kampar Provinsi Riau..

\section{DAFTAR PUSTAKA}

Assauri, S. (2009). Manajemen Pemasaran Konsep Dasar dan Strategi, edisi pertama. Jakarta: Rajagrafindo Persada

Buchory, Herry Achmad dan Saladin, Djaslim.2013. Manajemen Pemasaran:Teori, Aplikasi dan Tanya Jawab. Bandung: Linda Karya Bandung

Gasperz, V. 2009. Total Quality Manajemen. Jakarta: Gramedia Pustaka Utama

Husnul, Yetty Hayati dan Gracia Sekartaji Pengaruh Kualitas Produk terhadap Kepuasan Konsumen di Restoran Bebek dan Ayam Goreng Pak Ndut Solo. JIMFE (Jurnal Ilmiah Manajemen Fakultas Ekonomi) Volume 1 No. 1 Tahun 2015, Hal. 49-56. E-ISSN 2502-5678

Hurriyati, R.D. 2010. Bauran Pemasaran dan Loyalitas Pelanggan. Jakarta: Alfabeta CV

Irawan, Handi.2009. 10 Prinsip Kepuasan Pelanggan. PT Gramedia: Jakarta

Kotler, Philip. 2007. Manajemen Pemasaran. Jilid 1. Edisi Milenium. Jakarta: Prehallindo.

2008. Manajemen Pemasaran. Jilid II. Edisi Kesebelas. AlihBahasa Benyamin Molan.

Jakarta.: Indeks. 
Pengaruh kualitas produk terhadap kepuasan pelanggan keripik nenas di desa kualu nenas kecamatan tambang kabupaten kampar provinsi riau;

Dewi Sartika, Agustin Basriani

Kotler, Philip dan Amstrong. 2008. Prinsip-Prinsip Pemasaran. Jilid 1. Edisi Keduabelas. Jakarta: PT. Indeks.

Kotler, Philip dan Amstrong, Gary.2010. Prinsip Prinsip PemasaranEdisi 12. Jilid 2. Jakarta: Penerbit Erlangga

Kotler, Philip dan Keller, Kevin Lane. 2009. Manajemen Pemasaran. Edisi 13. Jilid 1. Jakarta: PT Erlangga

Kotler, Philip dan Lane, Kevin Lane. 2009.Manajemen Pemasaran. Edisi 13. Jilid 2. Jakarta: Penerbit Erlangga

Lupiyoadi, Rambat.2013. Manajemen Pemasaran Jasa. Edisi 3. Jakarta: Salemba Empat

Priyatno, Duwi. 2016. SPSS Handbook. Mediakom: Yogyakarta

Purnama, Suryani dan Rizki Sandrini.Analisis Pengaruh Kualitas Produk terhadap Kepuasan Konsumen Tas Sophie Paris. Forum Ilmiah Volume 9 Nomer 2, Mei 2012.

Rahim, T. 2012. Analisis Pengaruh Kualitas Produk dan Kualitas Pelayanan Terhadap Kepuasan Pelanggan di Amoole Distro. Pekanbaru.

Sanusi, Anwar. 2011. Metodologi Penelitian Bisnis. Salemba Empat: Jakarta

Sekartaji, G. 2015. Pengaruh Kualitas Produk Terhadap Kepuasan Pelanggan di Restoran Bebek dan Ayam Goreng Pak Ndut Solo. Vol 1, No 1 ISSN:2502-5678

Sudaryono. 2016.Manajemen Pemasaran: Teori dan Implementasi. Jogjakarta: Penerbit Andi Tjiptono, Fandi.2008. Strategi Pemasaran. Jogjakarta: Penerbit Andi 